\title{
Pengaruh Model Pembelajaran dan Kecerdasan Intelektual terhadap Hasil Belajar Bahasa Indonesia Baku
}

\author{
Sarce Sarah \\ Fakultas Pascasarjana, Universitas Indraprasta PGRI \\ Jalan Nangka No. 58 C/TB. Simatupang, Tanjung Barat, \\ Jakarta Selatan 12530
}

\begin{abstract}
The aims of this research are to analyze and to test the truth of the hypothesis concerning the influence of learning model and intellectual intelligence towards students' learning results of Indonesian language. This research was conducted by experimentation method. The population was students at eleven grade of SMAN Karawang amount 74 students which taken in random proportional. Research instrument that had been used was the Indonesian language test result in multiple choice form with 45 option question that has been tested homogeny as sig. 0,282 > 0,05 and Fh 1,234. Data analysis used analysis of variants (ANOVA) with two lines or way. The result of hypothesis test can be concluded were: 1) There was significant influence of learning model toward the students' learning result in learning Indonesian language, it has been proved with sig $=0,001$; sig $<0,05$ and $F h=13,782$. 2) There was significant influence of intellectual intelligence toward the students' learning result in learning Indonesian language, it has been proved with sig $=0,001 ;$ sig $<0,05$ and Fh 23,602. 3) There was no significant influence of learning model and intellectual intelligence toward the students' learning result in learning Indonesian language, it has been proved with interaction table test result sig=0,617;sig >0,05 and $F h=0,254$. The result of this research can be used to improve the quality of learning process and also to improve the ability of Indonesian language at senior high school level.

Key words: Learning model, intellectual intelligence, students' learning results of Indonesian language
\end{abstract}

\begin{abstract}
Abstrak
Penelitian bertujuan untuk menganalisis dan menguji kebenaran hipotesis mengenai pengaruh Model Pembelajaran dan Kecerdasan Intelektual terhadap Hasil Belajar Bahasa Indonesia Baku Siswa. Penelitian ini dilakukan dengan metode eksperimen. Populasi adalah siswa kelas XI SMA Negeri di Kabupaten Karawang dengan sampel sebanyak 74 siswa, dengan teknik random proporsional. Instrumen penelitian yang digunakan yaitu tes hasil belajar Bahasa Indonesia bentuk pilihan ganda dengan option sebanyak 45 soal yang telah diuji homogenitasnya dengan besar sig. 0,282 >0,05 dan F 1.324. Analisis data menggunakan analysis of varians (ANOVA) dua jalur/arah. Hasil pengujian hipotesis diperoleh kesimpulan sebagai berikut: 1) Terdapat pengaruh yang signifikan model pembelajaran terhadap hasil belajar bahasa indonesia baku siswa, hal tersebut dibuktikan dengan sig $=0,001$; sig $<0,05$ dan $F_{\text {hitung }}=13,782$. 2) Terdapat pengaruh yang signifikan kecerdasan intelektual hasil belajar bahasa indonesia baku siswa, hal tersebut dibuktikan dengan sig $=0,001 ;$ sig $<0,05$

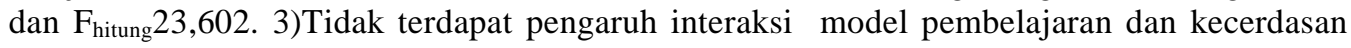
intelektual terhadap hasil belajar bahasa indonesia baku siswa, hal ini terbukti dengan hasil tabel uji interaksi diperoleh sig $=0,617$; sig $>0,05$ dan $F_{\text {hitung }}=0,254$. Hasil penelitian ini berguna untuk meningkatkan kualitas pembelajaran dan meningkatkan kemampuan berbahasa Indonesia baku di tingkat SMA.

Kata Kunci: Model Pembelajaran, Kecerdasan Intelektual, Hasil Belajar Bahasa Indonesia Baku
\end{abstract}

\section{PENDAHULUAN}

Pembelajaran bahasa sangat penting untuk diajarkan di sekolah-sekolah. Pembelajaran Bahasa Indonesia sebagai bahasa nasional harus lebih diarahkan 
pada kemampuan dan keterampilan siswa untuk berkomunikasi secara lisan maupun tulis. Kemampuan tersebut meliputi keterampilan mendengarkan, berbicara, membaca, dan menulis.

Bahasa memiliki peran yang sangat penting dalam dunia pendidikan. Dunia pendidikan pada saat ini memerlukan paradigma dalam menelaah proses pembelajaran dan interaksi antar siswa dan guru. Sudah seharusnya kegiatan pembelajaran juga lebih mempertimbangkan keaktifan dan kreatifitas siswa, Lie (2014:11-12), menjelaskan bahwa banyak penelitian dewasa ini menunjukan, mengenai pengajaran yang memberikan kesempatan pada siswa untuk bekerja sama dengan siswa lainya lebih efektif daripada pengajaran oleh guru. Peran yang ditunjukan guru pada situasi seperti ini hendaknya menjadi fasilitator.

Masalah-masalah yang muncul dalam proses pembelajaran di sekolah berdasarkan observasi awal, diantaranya adalah terkait dengan kesiapan siswa, kesiapan guru, dan perangkat yang digunakan, seperti metode, media, pendekatan dan model pembelajaran. Kesiapan guru dalam menyiapkan rancangan proses pembelajaran di kelas merupakan salah satu ujung tombak keberhasilan dalam pelaksanaanya di dalam kelas. Sampai saat ini, SMA Negeri 3 Karawang dan SMA Negeri 4 Karawang masih menggunakan Kurikulum 2013, namun dalam praktiknya masih berfokus kepada guru (teacher centered), sehingga dalam proses pembelajaran, guru lebih mendominasi dan menjadi pusat kegiatan dalam pembelajaran.

Pembelajaran yang efektif pada dasarnya harus sesuai dengan proses pembelajaran yang ideal, siswa diberikan kebebasan untuk mengemukakan pendapat, guru menggali kepercayaan diri siswa, menanamkan pemahaman kepada siswa dengan menggunakan berbagai model dan media pembelajaran yang bervariasi dalam suasana lingkungan kelas yang kondusif. Siswa memberikan pendapatnya serta berani mengajukan pertanyaan menjadi salah satu wujud partisipasi siswa guna keberhasilan dalam pembelajaran. Siswa seharusnya dapat menjelaskan sebuah jawaban dengan tepat. Keaktifan siswa akan memudahkan guru mengetahui sejauh mana keberhasilan mengajarnya dengan pemahaman siswa yang belum jelas atau masih ragu-ragu terhadap masalah yang disampaikan.

Kecerdasan intelektual menentukan keberhasilan siswa dalam mengembangkan potensi yang ada dalam diri masing-masing siswa. Model pengajaran yang teratur dan terencana dalam kegiatan pembelajaran dapat mencapai tujuan pengajaran serta mampu membuat siswa menjadi aktif dalam proses pembelajaran. Student oriented perlu ditanamkan pada kurikulum 2013. Peran guru juga sangat penting dalam dunia pendidikan diantaranya, sebagai motivator dan juga sebagai fasilitator untuk membantu siswa dalam belajar. Guru memiliki tanggung jawab melihat segala yang yang terjadi di dalam kelas guna membantu proses perkembangan siswa. Keberhasilan suatu pendidikan terkait dengan masalah untuk mencapai keberhasilan dalam proses belajar mengajar di sekolah. Proses belajar mengajar akan lebih efektif dan efisien apabila siswa ikut aktif berpartisipasi di dalamnya. Upaya meningkatkan hasil belajar bahasa Indonesia baku, proses pembelajaran harus dikemas sebaik mungkin sehingga 
menarik yakni dengan memilih dan menerapkan model pembelajaran yang memungkinkan pemahaman siswa terhadap pembelajaran bahasa Indonesia baku.

Model pembelajaran numbered heads together (NHT) merupakan model pembelajaran yang kesempatan kepada siswa untuk turut aktif dalam mengemukakan pendapat dalam sebuah diskusi. Model pembelajaran NHT akan meningkatkan rasa tanggung jawab setiap individu siswa. Penerapan model NHT dalam pembelajaran, membuat guru dapat mengevaluasi sejauh mana siswa memahami materi yang sedang dipelajari. Setiap siswa memiliki tingkat kecerdasan intelektual yang berbeda. Siswa yang memiliki kecerdasan intelektual tinggi akan turut aktif memberikan pendapatnya. Hal itu tentu akan memberikan dorongan kepada siswa lain untuk turut serta di dalamnya, sehingga diharapkan dapat mempengaruhi hasil belajar bahasa Indonesia baku siswa.

Model pembelajaran NHT dirasa cukup tepat untuk digunakan, agar siswa dapat mengembangkan kecerdasan intelektualnya dalam pelajaran bahasa Indonesia. Siswa yang memiliki tingkat kecerdasan intelektual yang tinggi akan lebih mampu memecahkan masalah, menganalisis serta memahami materi. Penelitian ini perlu dilakukan karena melalui model pembelajaran NHT dapat mempengaruhi hasil belajar bahasa Indonesia siswa didukung dengan tingkat kecerdasan intelektual yang dimiliki, oleh karena itu penelitian ini dikhususkan untuk mengetahui pengaruh model pembelajaran dan kecerdasan intelektual terhadap hasil belajar bahasa Indonesia baku siswa pada SMA Negeri di Kabupaten Karawang.

Ada banyak pengertian bahasa yang dikemukakan para ahli, salah satunya adalah Kridalaksana (dalam Lapasau dan Arifin, 2016:1), mengatakan bahwa "Bahasa adalah sistem lambang bunyi yang arbitrer yang digunakan oleh para anggota kelompok sosial untuk bekerjasama, berkomunikasi, dan mengidentifikasi diri”. Brown (dalam Arifin, 2016:12) mengemukakan delapan hakikat bahasa, yaitu Bahasa itu sistematik, arbitrer, Simbol-simbol, konvensional, Bahasa beroperasi atau digunakan dalam sebuah komunitas atau masyarakat tertentu dengan budaya wicara tertentu pula, Bahasa pada dasarnya untuk manusia walaupun bisa jadi tidak hanya terbatas untuk manusia, dan Bahasa dikuasai oleh semua orang dalam cara yang sama, bahasa dan pengajaran bahasa sama-sama mempunyai karakteristik unversal.

Bahasa Indonesia yang baik dan benar adalah bahasa Indonesia yang digunakan sesuai dengan norma kemasyarakatan yang berlaku dan sesuai pula dengan kaidah bahasa Indonesia yang sudah disepakati (Arifin:2016). Fungsi Bahasa Indonesia baku sebagai bahasa nasional mempunyai empat fungsi, yaitu 1) lambang identitas nasional ,2) lambang kebanggaan nasional, 3) alat pemersatu, 4) alat perhubungan antar warga. (Arifin, dkk:2015). Penggunaan bahasa dengan baik menekankan aspek komunikatif bahasa. Hal itu berarti bahwa kita harus memperhatikan sasaran bahasa kita. Kita harus memperhatikan kepada siapa kita akan menyampaikan bahasa kita. Oleh sebab itu, unsur umur, pendidikan, agama, status sosial, lingkungan sosial, dan sudut pandang khalayak sasaran, kita tidak boleh kita abaikan. 
Sudjana (2010:22) menambahkan, hasil belajar adalah kemampuan setelah menerima pengalaman belajar. Beliau juga mengklasifikasi hasil belajar dari Bloom dibagi menjadi tiga ranah, yaitu Ranah kognitif, Ranah afektif, dan Ranah psikomotorik. Anderson (2001:215-216), merevisi domain kognitif dalam taksonomi tujuan pendidikan Bloom. Domain kognitif dibagi menjadi dua dimensi yang pertama dimensi pengetahuan yang terdiri dari pengetahuan faktual konseptual, prosedural dan metakognitif. Kedua, dimensi proses kognitif yang terdiri dari mengingat, memahami, mengaplikasikan, menganalisis, mengevaluasi, dan mencipta. Kognitif didentikan dengan pengetahuan dan proses kognitif. Kedua bentuk tersebut menjadi salah satu gambaran luas mengenai kognitif.

Model pembelajaran menjadi suatu rancangan yang dibutuhkan dalam proses belajar. Model pembelajaran juga dipandang sebagai suatu usaha dalam proses pembelajaran yang dilakukan guru untuk meng- atasi masalah - masalah yang sering dialami. Model pembelajaran merupakan sebuah pola perencanaan sebagai pedoman dalam merancang sebuah pembelajran yang akan diberikan maupun tutorial.

Model pembelajaran Numbered Heads Together (NHT) dikembangkan pertama kali oleh Kagan pada tahun 1993. Model ini melibatkan banyak siswa untuk mengkaji sebuah materi pelajaran dan mengetahui pemahaman siswa dalam materi tersebut.(Trianto,2015:131). NHT dirancang dalam sebuah proses pembelajaran agar dapat memudahkan siswa dalam memahami permasalahan yang diberikan seorang guru.

Acher (2011:149), menyatakan bahwa NHT masuk ke dalam model pembelajaran kooperatif (kooperatif learning), prosesnya menggunakan kelompok kecil yang nantinya akan membuat siswa dapat bekerja sama dalam memaksimalkan kelompok mereka. Kelompok dalam NHT dipilih berdasarkan kemampuan, etnis dan jenis kelamin yang berbeda. Proses dalam penerapan NHT seorang guru akan memilih siswa dalam sebuah kelompok agar dapat saling melengkapi satu dengan yang lain.

Pendapat yang sama dari Slavin (2009:8), bahwa pada proses pembelajaran kooperatif, siswa akan duduk bersama dalam sebuah kelompok. Setiap kelompok beranggotakan empat orang untuk menjawab pertanyaan yang diberikan oleh guru. Penerapan pembelajaran kooperatif memiliki tujuan untuk memberikan siswa pengetahuan, konsep, kemampuan dan pemahaman yang mereka butuhkan agar berkontribusi dalam sebuah diskusi baik dalam lingkungan sekolah maupun lingkungan masyarakat. Proses pembelajaran kooperatif memiliki tujuan agar siswa dapat memiliki rasa tanggung jawab dalam sebuah permasalahan dalam sebuah kelompok baik yang berada dalam lingkungan sekolah maupun lingkungan masyarakat.

Pada proses pembelajaran NHT siswa akan ditinjau oleh guru, agar dapat mencapai sesuai dengan tujuan pembelajaran. Model NHT menurut McMillen (2014:65), dirancang agar semua siswa turut aktif dalam memberikan tanggapannya dari pertanyaan yang diberikan oleh guru dalam sebuah diskusi. Keaktifan siswa secara langsung akan mempengaruhi nilai akademik siswa. 
Adanya keaktifan siswa dalam belajar tentu akan membantu seorang guru dalam menilai siswa dari segi pemahamannya. Pembelajaran dengan menggunakan NHT, siswa akan belajar dengan teman-temanya yang berasal dari berbagai latar belakang hal ini tentu akan mempengaruhi hasil belajar siswa. Siswa akan saling melengkapi satu dengan yang lainnya dalam proses pembelajaran.

Berdasarkan pemaparan dari beberapa ahli di atas, dapat disimpulkan bahwa NHT merupakan salah satu model pembelajaran, yang termasuk ke dalam pembelajaran kooperatif. Model NHT akan melibatkan banyak siswa pada sebuah diskusi dalam mengkaji sebuah permasalahan yang diajukan oleh guru. Penerapan dari model NHT ini menggunakan nomor yang diletakan diatas kepala yang bertujuan untuk berfikir bersama, dan berharap dapat mempengaruhi hasil belajar terutama dalam bidang akademik.

Model konvensional sering disebut sebagai model pembelajaran ynag sering dilakukan oleh guru pada setiap pembelajaran. Sanjaya (2006:147), mengungkapkan bahwa metode ceramah merupakan metode yang sampai saat ini sering digunakan oleh setiap guru atau instruktur. Model ceramah siswa hanya mendengarkan, sehingga siswa menjadi pasif. Kesempatan yang diberikan kepada siswa sangat sedikit untuk turut aktif dalam pembelajaran. Kontribusi siswa dalam pembelajaran yang minim mengakibatkan turut mempengaruhi keterampilan serta sikap dalam pembelajaran yang dilakukan. Model pembelajaran konvensional ini jelas didominasi oleh guru dengan model ceramah dan tanya jawab.

Berdasarkan pendapat-pendapat para ahli tersebut diatas dapat disimpulkan bahwa pembelajaran konvensional lebih berorientasi pada guru, peran guru jauh lebih besar dari siswa. Siswa ditempatkan sebagai obyek belajar, yang tidak berkesempatam mengembangkan daya pikirnya. Kesempatan untuk berinteraksi antara siswa dengan siswa, antara siswa dengan guru, antara siswa dengan lingkungan belajarnya dan antara siswa dengan bahan ajar untuk memecahkan masalah sangat terbatas.

Kecerdasan intelektual atau disebut dengan Intellegence Quotient (IQ) akan mampu memprediksi seberapa mampu seorang individu belajar. Menurut Djaali (2013:64-65), bahwa intelegensi berasal dari kata intelegence yang berarti menghubungkan atau menyatukan. Seseorang dapat dikategorikan sebagai orang yang cerdas, bila mempunyai kemampuan berfikir abstrak secara benar dan atau tepat. Kecerdasan ini lebih menekankan pada kemampuan belajar dengan tujuan untuk mencapai prestasi dalam aspek akademik.

Intelegensi menunjukkan kepada bagaimana cara individu berperilaku atau cara bagaimana individu bertindak, apakah individu bertindak secara inlegen atau tidak intelegen. Kemampuan memecahkan masalah, kemampuan verbal dipengaruhi oleh kecerdasan intelektual. Setiap siswa memiliki kemampuan yang berbeda tergantung pada seberapa tinggi kemampuan kecerdasan intelektualnya.

Kecerdasan intelektual menurut Miller, tidak dapat diukur hanya dengan satu pengukuran. Pengukuran utama dilakukan dengan menggunakan tiga pengukuran yakni melalui kemampuan verbal, kemampuan matematika dan kemampuan ruang. Pengukuran kecerdasan biasa dilakukan oleh para lembaga IQ. 
Intelegensi memang memainkan peranan yang signifikan dalam proses pembelajaran, namun masih banyak faktor lain yang juga turut serta di dalamnya, diantaranya adanya motivasi, mutu pengajaran, fasilitas dalam keluarga, dukungan orang tua, harapan teman-teman sebaya, dan sebagainya.

Salah satu upaya yang dapat dilakukan untuk mempengaruhi hasil belajar Bahasa Indonesia dan siswa menjadi aktif adalah yang mengikuti model pembelajaran NHT. Model NHT dilakukan untuk mendorong siswa turut serta dalam pembelajaran di kelas. Siswa dapat menambah wawasan karena saling memberikan pendapatnya. Model NHT akan menjadi sebuah snow ball, materi yang digunakan akan menjadikan siswa memiliki rasa tanggung jawab terhadap tugas yang diberikan oleh guru. Model NHT perlu didukung dengan kecerdasan intelektual. Kecerdasan intelektual merupakan sebuah kemampuan untuk menghadapi abstraksi, memecahkan masalah serta untuk belajar. Model NHT dengan kecerdasan intelektual, dirasa tepat digunakan dalam pembelajaran Bahasa Indonesia. Setiap siswa memiliki pemahaman berbeda-beda dalam mengungkapkan pendapat, ide, dan informasi dalam sebuah permasalahan.

Model NHT dan kecerdasan intelektual, akan membuat siswa memperoleh ide atau informasi dari siswa lainnya. Siswa diberikan tanggung jawab untuk menyelesaikan tugas dalam kelompoknya. Model pembelajaran NHT dengan kecerdasan intelektual ini dimulai dengan membagi siswa menjadi beberapa kelompok, setiap kelompok terdiri empat orang yang masing-masing memiliki nomor kepala 1, 2, 3, 4. Siswa diberikan pertanyaan seputar materi yang sedang diajarkan. Guru akan memilih siswa untuk mempresentasikan hasil kajiannya di depan kelas. Pendapat siswa terarah dan bermakna sehingga sesuai dengan pembahasan, oleh karena itu kecerdasan intelektual turut mendukung dalam proses pembelajaran. Pada akhirnya seluruh anggota kelompok memiliki pemahaman yang sama mengenai materi yang sedang dibahas.

Berbeda dengan model pembelajaran konvensional, dalam proses pembelajarannya siswa lebih pasif, siswa hanya mendengarkan dan memperhatikan guru, meskipun sesekali berdiskusi namun tidak terarah hal ini yang menjadikan proses pembelajaran terkesan monoton. Tidak jarang guru menjadi satu-satunya sumber yang didapatkan siswa dalam proses pembelajaran. Siswa tidak turut serta dalam menganalisis. Berdasarkan penjelasan di atas diduga hasil belajar Bahasa Indonesia siswa yang mengikuti model pembelajaran NHT lebih tinggi dari siswa yang mengikuti model pembelajaran konvensional.

Proses dalam menerima, menyimpan dan mengolah kembali informasi. Siswa yang memiliki kecerdasan intelektual tinggi jika mengikuti model pembelajaran NHT akan terlibat langsung dalam proses pembelajaran. Siswa yang memiliki kecerdasan intelektual tinggi tidak akan terlibat langsung sepenuhnya dalam proses pembelajaran jika mengikuti model pembelajaran konvensional. Guru akan mendominasi dalam proses pembelajaran, siswa hanya memiliki waktu yang terbatas dalam mengungkapkan pendapatnya. Berdasarkan uraian diatas diduga terdapat perbedaan hasil belajar bahasa Indonesia antara 
siswa yang mengikuti model pembelajaran NHT dan kecerdasan intelektual tinggi dengan siswa yang mengikuti model pembelajaran konvensional dan kecerdasan intelektual tinggi.

Penggunaan model pembelajaran NHT jika dilakukan pada siswa yang memiliki kecerdasan intelektual rendah akan mengalami kesulitan. Model pembelajaran NHT merupakan suatu bentuk diskusi dalam rangka menghimpun gagasan, pendapat, informasi, pengetahuan, pengalaman dari semua siswa. Siswa yang memiliki kecerdasan intelektual rendah sering tertinggal dalam menanggapi permasalahan yang diajukan oleh guru. Kecerdasan dapat dikatakan di mana seseorang dapat membandingkan, menganalisis, menemukan, mendesain yang dapat diterapkan atau digunakan dalam kehidupan.

Pembelajaran bahasa Indonesia merupakan pembelajaran yang bukan sekedar menghafal teori-teori kebahasaan saja, namun siswa dihadapkan dengan tantangan intelektual. Artinya, tujuan pembelajaran bahasa Indonesia dapat mengtransformasikan pengetahuan tentang bahasa Indonesia dan bagaimana penggunaannya yang efektif, melalui pembelajaran bahasa Indonesia siswa juga belajar bagaimana bahasa Indonesia memungkinkan orang saling berinteraksi secara efektif; membangun dan membina hubungan; memgungkapkan dan mempertukarkan pengetahuan, keterampilan, sikap, perasaan dan pendapat, namun pembelajaran bahasa Indonesia sering terkesan membosankan bagi siswa karena penerapan model pembelajaran yang diterapkan kurang tepat. Setiap siswa memiliki kecerdasan intelektual yang berbeda. Model pembelajaran yang digunakan guru dalam pembelajaran bahasa Indonesia harus dapat meilhat tingkat kecerdasan intelektual siswa. Berdasarkan uraian di atas diduga terdapat interaksi antara model pembelajaran dan kecerdasan intelektual siswa terhadap hasil belajar bahasa Indonesia baku. Berdasarkan deskripsi teoretik dan kerangka berpikir tersebut penelitian ini bertujuan menguji pengaruh model pembelajaran dan kecerdasan intelektual terhadap hasil belajar bahasa Indonesia baku

\section{METODE}

Metode penelitian yang digunakan dalam penelitian ini adalah eksperimen. Pendekatan eksperimen digunakan untuk menjelaskan pengaruh antara variabel penelitian. Desain yang digunakan treament by level $2 \times 2$. Variabel yang digunakan dalam penelitian ini terdapat dua variabel yaitu variabel bebas dan variabel terikat. Model pembelajaran NHT (X1) dan kecerdasan intelektual (X2) ditetapkan sebagai variabel bebas, sedangkan hasil belajar bahasa Indonesiabaku siswa (Y) sebagai variabel terikat.

Tabel 1. Desain Penelitian Eksperimen

\begin{tabular}{ccc}
\hline $\begin{array}{l}\text { Kecerdasan } \\
\text { Intelektual }\end{array}$ & \multicolumn{2}{c}{ Model Pembelajaran } \\
KHT $\left(\mathrm{A}_{1}\right)$ & $\begin{array}{c}\text { Konvensional } \\
\left(\mathrm{A}_{2}\right)\end{array}$ \\
\hline Tinggi $\left(\mathrm{B}_{1}\right)$ & $\mathrm{A}_{1} \mathrm{~B}_{1}$ & $\mathrm{~A}_{2} \mathrm{~B}_{1}$ \\
\hline
\end{tabular}


Diskursus: Jurnal Pendidikan Bahasa Indonesia

Vol. 1, No. 1, April 2018, pp. 82-96

p-ISSN: $2615-4935$

e-ISSN: 2615-4943

\begin{tabular}{ccc}
\hline Rendah $\left(\mathrm{B}_{2}\right)$ & $\mathrm{A}_{1} \mathrm{~B}_{2}$ & $\mathrm{~A}_{2} \mathrm{~B}_{2}$ \\
\hline
\end{tabular}

Keterangan :

$\mathrm{A}_{1} \mathrm{~B}_{1}=$ kelompok siswa yang diberikan perlakuan model pembelajaran NHT dengan kecerdasan intelektual tinggi.

$\mathrm{A}_{1} \mathrm{~B}_{2}=$ kelompok siswa yang diberikan perlakuan model pembelajaran NHT dengan kecerdasan intelektual rendah

$\mathrm{A}_{2} \mathrm{~B}_{1}=$ kelompok siswa yang diberikan perlakuan model pembelajaran konvensional dengan kecerdasan intelektual tinggi.

$\mathrm{A}_{2} \mathrm{~B}_{2}=$ kelompok siswa yang diberikan perlakuan model pembelajaran konvensional dengan kecerdasan intelektual rendah

$\mathrm{A}_{1} \quad=$ Perlakuan model pembelajaran NHT

$\mathrm{A}_{2} \quad=$ Perlakuan model pembelajaran konvensional

Sampel adalah sebagian dari populasi yang memiliki sifat sama dengan populasi (Sudjana, 1998: 85). Sampel adalah sebagian atau wakil populasi yang diteliti (Arikunto, 1996: 104). Setelah diketahui hasil randomisasi, jika kelas-kelas yang menjadi populasi tersebut memiliki peluang atau kesempatan yang sama untuk dijadikan sebagai sampel penelitian, maka akan ditetapkan secara random. Adapun sampel dalam penelitian ini adalah sebanyak $10 \%$ X $748=74,8$ dan untuk memudahkan penelitian diambil menjadi 74 siswa, sehingga dapat memudahkan dalam membagi kelas yaitu kelas kontrol dan kelas eksperimen. Masing-masing kelas dibagi menjadi dua bagian kecerdasan intelektual tinggi dan rendah. Setelah diambil secara random, terpilih kelas XI IPA 4 dari SMA Negeri 3 sebagai kelas eksperimen sebanyak 37 siswa dan kelas XI 2 SMA Negeri 4 sebagai kelas kontrol sebanyak 37 siswa. Dari sampel masing masing kelas yang telah terpilih secara acak diurutkan kecerdasan intelektualnya dari yang skor yang paling tinggi sampai yang terendah, kemudian diambil $27 \%$ dari data tertingi dan $27 \%$ dari data paling rendah .

Uji normalitas penelitian ini menggunakan uji Liliefors. Pengujiian homogenitas menggunakan uji Barlett, untuk mengetahui apakah variansi kelompok homogen atau tidak. Pengujian hipotesis dalam penelitian ini menggunakan analisis varians dua jalur (ANAVA 2X2). Perbedaan hasil belajar Bahasa Indonesia melalui model kelompok dan konvensional serta untuk mengetahui signifikasi interaksi yang ada antara model pembelajaran dengan kecerdasan intelektual yang terbagi kedalam kecerdasan intelektual tinggi dan rendah dapat diketahui dengan uji hipotesis ANAVA dua jalur dengan cara membandingkan $\mathrm{F}$ hitung dengan $\mathrm{F}$ tabel pada setiap faktor perlakuan (A dan B) dan interaksi antara faktor (A x B), setelah diperoleh angka yang menunjukan adanya interaksi dari pengaruh utama variabel bebas dengan variabel terikat maka dianalisis dengan Uji Tuckey dengan taraf signifikansi

$$
\alpha=0,05 \text {. }
$$

\section{HASIL DAN PEMBAHASAN}


Data yang diperoleh dari pemberian tes untuk mengetahui hasil belajar bahasa Indonesia baku dan data yang diperoleh dari SMAN 3 Karawang dan SMAN 4 Karawang. Hasil skor dari pengukuran disusun berdasarkan skor tertinggi ke skor yang terendah. Skor hasil belajar bahasa Indonesia baku siswa yang diperoleh diubah menjadi nilai dengan rumus: $\frac{\text { skor perolehan }}{\text { skor maksimum }}$ X 100, Nilai yang diperoleh kemudian dikelompokan berdasarkan kelas eksperimen yang menggunakan model pembelajaran NHT (A1) dan kelas kontrol yang menggunakan model pembelajaran konvensional (A2) serta melihat kecerdasan intelektual tinggi (B1) dan kecerdasan intelektual rendah (B2). Selain itu, gabungan dari model pembelajaran NHT dan kecerdasan intelektual tinggi (A1B1), model pembelajaran konvensional dan kecerdasan intelektual tinggi (A2B1), model pembelajaran NHT dan kecerdasan intelek- tual rendah (A1B2), model pembelajaran konvensional dan kecerdasan intelektual rendah (A2B2) dapat terlihat dari tabel sebagai berikut :

Tabel 2. Nilai Hasil Belajar Bahasa Indonesia Baku

\begin{tabular}{|c|c|c|c|c|}
\hline \multirow{2}{*}{$\begin{array}{l}\text { Kecerintel } \\
\text { ektual }\end{array}$} & \multicolumn{2}{|c|}{ Model pembelajaran } & \multirow{2}{*}{\multicolumn{2}{|c|}{$\Sigma \mathrm{B}$}} \\
\hline & $\begin{array}{l}\text { NHT } \\
\text { (AI) }\end{array}$ & Konvensional (A.2) & & \\
\hline$\underset{(\mathrm{B} 1)}{\text { Tinggi }}$ & $\begin{array}{l}98 \\
87 \\
96 \\
82 \\
93 \\
84 \\
96 \\
89 \\
76\end{array}$ & $\begin{array}{l}84 \\
82 \\
93 \\
80 \\
89 \\
80 \\
73 \\
78 \\
68 \\
64\end{array}$ & $\begin{array}{l}98 \\
87 \\
96 \\
82 \\
93 \\
84 \\
96 \\
89 \\
76 \\
82\end{array}$ & $\begin{array}{c}84 \\
82 \\
93 \\
80 \\
89 \\
80 \\
7 \\
78 \\
68 \\
64\end{array}$ \\
\hline $\begin{array}{c}\text { Rendah } \\
\text { (B2) }\end{array}$ & $\begin{array}{r}84 \\
78 \\
73 \\
73 \\
76 \\
84 \\
76 \\
73 \\
78 \\
71\end{array}$ & $\begin{array}{l}71 \\
60 \\
78 \\
71 \\
67 \\
80 \\
67 \\
64 \\
31\end{array}$ & $\begin{array}{l}84 \\
78 \\
73 \\
73 \\
76 \\
84 \\
76 \\
73 \\
78 \\
71\end{array}$ & $\begin{array}{l}71 \\
60 \\
78 \\
71 \\
67 \\
80 \\
67 \\
64 \\
71 \\
67\end{array}$ \\
\hline
\end{tabular}

\begin{tabular}{lllllllll}
\hline & 4 & 8 & 4 & 1 & 4 & 8 & 4 & 1 \\
$5 \mathrm{~K}$ & 8 & 7 & 2 & 0 & 8 & 7 & 2 & 0 \\
& 3 & 6 & 3 & 8 & 3 & 6 & 3 & 8 \\
& 3 & 2 & 0 & 1 & 3 & 2 & 0 & 1 \\
& 6 & 3 & 9 & 7 & 6 & 3 & 9 & 7 \\
& 4 & 4 & 0 & 0 & 4 & 4 & 0 & 0 \\
& 6 & 6 & 3 & 7 & 6 & 6 & 3 & 7 \\
& 3 & 9 & 8 & 4 & 3 & 9 & 8 & 4 \\
& 1 & 6 & 8 & 1 & 8 & 6 & 8 & 1 \\
\hline
\end{tabular}


Berdasarkan nilai hasil belajar bahasa Indonesia baku siswa, kemudian menggunakan perhitungan excel seperti terlihat pada tabel berikut:

Tabel 3. Rangkuman Hasil Belajar Bahasa Indonesia Baku

\begin{tabular}{|c|c|c|c|}
\hline \multirow{2}{*}{$\begin{array}{c}\text { Kecerdas } \\
\text { an intelektual } \\
\text { (B) }\end{array}$} & \multicolumn{2}{|c|}{ Model pembelajaran (A) } & \multirow[b]{2}{*}{$\sum \mathrm{B}$} \\
\hline & NHT (A1) & $\begin{array}{l}\text { Konvensional } \\
\text { (A2) }\end{array}$ & \\
\hline & $=10^{\mathrm{n}}$ & $=10^{\mathrm{n}}$ & $=20^{\mathrm{n}}$ \\
\hline $\begin{array}{l}\text { Tinggi } \\
\text { (B1) }\end{array}$ & $88,30^{\bar{X}=}$ & $79,10^{\bar{X}=}$ & $\begin{array}{r}\bar{X} \\
=83,70\end{array}$ \\
\hline & $7_{7,349} S=$ & ${ }_{8,913} S=$ & $\begin{array}{r}S \\
=9,246\end{array}$ \\
\hline Renda & $=10 \begin{array}{l}\mathrm{n} \\
\overline{\bar{X}}-\end{array}$ & $=10^{\mathrm{n}}$ & $=20^{n}$ \\
\hline h & ${ }_{4,526}^{76,60}{ }^{\Lambda=}$ & $\begin{array}{l}69,60{ }_{S}^{\Lambda=} \\
=6,041\end{array}$ & $\begin{array}{r}=73,10 \\
S \\
=6,315\end{array}$ \\
\hline$\sum \mathrm{K}$ & ${ }_{82,44}{ }^{\mathrm{n}} \overline{\bar{X}}=$ & $\begin{array}{l}=20{ }^{\mathrm{n}} \\
74,40 \\
8.68\end{array}$ & 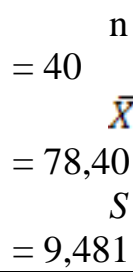 \\
\hline
\end{tabular}

Tabel 4. Deskripsi statistik

\begin{tabular}{|c|c|c|c|c|}
\hline & ndent Variable: Has & Bahasa & donesia Baku & \\
\hline $\begin{array}{r}\text { Model } \\
\text { Pembelajaran }\end{array}$ & $\begin{array}{l}\text { Kecerdasan } \\
\text { Intelektual }\end{array}$ & $a^{M e}$ & $\begin{array}{c}\text { Std. } \\
\text { Deviation }\end{array}$ & $\mathrm{N}$ \\
\hline & Tinggi & $\begin{array}{r}88 . \\
30\end{array}$ & 7.349 & 10 \\
\hline NHT & Rendah & $\begin{array}{r}76 . \\
60\end{array}$ & 4.526 & 10 \\
\hline & Total & $\begin{array}{r}82 . \\
45\end{array}$ & 8.445 & 20 \\
\hline & Tinggi & $\begin{array}{r}79 . \\
10\end{array}$ & 8.913 & 10 \\
\hline Konvensional & Rendah & $\begin{array}{l}69 . \\
60\end{array}$ & 6.041 & 10 \\
\hline & Total & $\begin{array}{r}74 . \\
35\end{array}$ & 8.869 & 20 \\
\hline TTtal & Tinggi & $\begin{array}{r}83 . \\
70\end{array}$ & 9.246 & 20 \\
\hline Tular & Rendah & $\begin{array}{r}73 . \\
10\end{array}$ & 6.315 & 20 \\
\hline
\end{tabular}




\begin{tabular}{cccc}
\hline Total & 78. & 9.481 & 40 \\
\hline
\end{tabular}

Berdasarkan tabel tersebut, dapat diketahui bahwa penggunaan model pembelajaran NHT lebih efektif karena memberikan kontribusi hasil belajar bahasa Indonesia baku yang jauh lebih besar dibandingkan dengan model pembelajaran konvensional. Hal ini dapat diamati pada tabel rata-rata hasil belajar bahasa Indonesia baku $(82,45>74,35)$, sehingga model pembelajaran NHT perlu dipertimbangkan dalam pembelajaran bahasa Indonesia di sekolah. Berdasarkan tabel diatas, dapat diketahui pula kecerdasan intelektual tinggi memberikan kontribusi yang lebih besar dibandingkan dengan kecerdasan intelektual rendah. Hal ini dapat dilihat pada tabel rata-rata $(88,30>76,60)$, sehingga kecerdasan intelektual siswa juga merupakan faktor yang perlu dipertimbangkan dalam memberikan pelajaran Bahasa Indonesia

Untuk mengetahui data hasil belajar bahasa Indonesia baku normal, maka dilakukan pengujian normalitas dependent variable dengan perhitungan SPSS 24.0, sehingga diperoleh tabel One-Sample Kolmogorov-Smirnov Tes. Kriteria jika sig > 0,05 , maka hipotesis yang menyatakan variable dependent adalah normal bisa diterima. Pada data penelitian menunjukan sig $=0,899>0,05$, maka data adalah berdistribusi normal seperti terlihat pada tabel berikut.

Tabel 5.

\section{One-Sample Kolmogorov-Smirnov Test}

\begin{tabular}{|c|c|c|}
\hline \multicolumn{3}{|c|}{ One-Sample Kolmogorov-Smirnov Test } \\
\hline \multirow{3}{*}{$\mathrm{N}$} & & \\
\hline & & 40 \\
\hline & Mean & 78.40 \\
\hline \multirow[t]{2}{*}{ Normal Parameters ${ }^{\mathrm{a}, \mathrm{b}}$} & Std. & 0481 \\
\hline & ation & 9.401 \\
\hline \multirow{5}{*}{$\begin{array}{r}\text { Most } \\
\text { Differences }\end{array}$} & Absolut & 001 \\
\hline & & .091. \\
\hline & Positive & .091 \\
\hline & Negativ & -063 \\
\hline & & \\
\hline \multicolumn{2}{|l|}{ Kolmogorov-Smirnov Z } & .572 \\
\hline \multicolumn{2}{|l|}{ Asymp. Sig. (2-tailed) } & .899 \\
\hline \multicolumn{3}{|c|}{ a. Test distribution is Normal. } \\
\hline \multicolumn{2}{|c|}{ b. Calculated from data. } & \\
\hline
\end{tabular}

Pengujian homogenitas dilakukan untuk mengetahui apakah varian populasi bersifat homogen atau tidak karena selain uji normalitas, salah satu syarat yang diperlukan dalam menganalisis data dengan menggunakan ANOVA adalah uji homogenitas. Ringkasan hasil perhitungan uji homogenitas kelompok sampel dapat dilihat pada tabel Levene's untuk menguji homogenitas dependent variabel pada hasil belajar bahasa Indonesia baku. Pengujian homogenitas pada data kelompok sampel dilakukan dengan uji bartlet pada taraf signifikan $\alpha=5 \%$.

\section{Tabel 6}


Levene's Test of Equality of Error Variances ${ }^{\mathrm{a}}$

Dependent Variable: Hasil Belajar Bahasa Indonesia Baku

$\begin{array}{cccc}\text { F } & \text { df1 } & \text { df2 } & \text { Sig. } \\ 1.324 & 3 & 36 & .282\end{array}$

Tests the null hypothesis that the error variance of the dependent variable is equal across groups.

a. Design: Intercept $+\mathrm{A}+\mathrm{B}+\mathrm{A} * \mathrm{~B}$

Kelompok sampel pada data kelompok hasil belajar bahasaIndonesia baku, setelah dilakukan pengujian SPSS 24.0 Memperoleh homogenitas dengan nilai Probabilitas Sig $=0,282$. Karena nilai probabilitas $\mathrm{Sig}>0,05$ maka varian populasi homogen.

Pengujian hipotesis penelitian dianalisis menggunakan ANOVA dua faktor untuk mengetahui pengaruh dan interaksi antar kelompok. Analisis ANOVA ini menggunakan perhitungan SPSS 24.0 pada tabel sebagai berikut:

Tabel 7.

Tests of Between-Subjects Effects

Dependent Variable: Hasil Belajar Bahasa Indonesia Baku

\begin{tabular}{llllll}
\hline Source & \multicolumn{2}{l}{$\begin{array}{l}\text { Type III Sum ofDf } \\
\text { Squares }\end{array}$} & Mean Square & F & Sig. \\
Corrected Model & $1791.800^{\mathrm{a}}$ & 3 & 597.267 & 12.546 & .000 \\
Intercept & 245862.400 & 1 & 245862.400 & 5164.574 & .000 \\
$\mathrm{~A}$ & 656.100 & 1 & 656.100 & 13.782 & .001 \\
$\mathrm{~B}$ & 1123.600 & 1 & 1123.600 & 23.602 & .000 \\
$\mathrm{~A} * \mathrm{~B}$ & 12.100 & 1 & 12.100 & .254 & .617 \\
Error & 1713.800 & 36 & 47.606 & & \\
Total & 249368.000 & 40 & & & \\
Corrected Total & 3505.600 & 39 & & \\
a. R Squared $=.511$ (Adjusted R Squared $=.470)$ & & \\
\hline
\end{tabular}

\section{Pengujian Hipotesisi 1}

Terdapat pengaruh yang signifikan model pembelajaran terhadap hasil belajar Bahasa Indonesia Baku siswa. Hipotesis ini diuji dengan melihat koefisien signifikan. Jika nilai sig > 0,05; maka Ho diterima dan $\mathrm{H}_{1}$ ditolak. Sebaliknya jika nilai sig < 0,05; maka $\mathrm{H}_{1}$ diterima dan Ho ditolak. Untuk pengujian hipotesis pengaruh model pembelajaran terhadap hasil belajar bahasa Indonesia baku menggunakan SPSS 24.0. Dari tabel di atas, diperoleh nilai Sig $=0,001<0,05$, ini memilki makna bahwa apabila nilai sig $<0,05$, maka $\mathrm{H} 1$ diterima dan $\mathrm{H} 0$ ditolak yang berarti terdapat pengaruh yang signifikan model pembelajaran terhadap hasil belajar bahasa Indonesia baku. Sementara $F_{\text {hitung }}=13,782$ dan $F_{\text {tabel }}=4,41$, ini memiliki makna lebih memperjelas bahwa model pembelajaran memiliki pengaruh yang signifikan terhadap hasil belajar bahasa Indonesia baku.

\section{Pengujian hipotesis 2}

Terdapat pengaruh yang signifikan kecerdasan intelektual terhadap hasil belajar bahasa Indonesia baku siswa. Hipotesis ini diuji dengan melihat koefisien signifikan. Jika nilai sig $>0,05$; maka Ho diterima dan $\mathrm{H}_{1}$ ditolak. Sebaliknya jika nilai sig < 0,05; 
maka $\mathrm{H}_{1}$ diterma dan Ho ditolak. Untuk pengujian hipotesis pengaruh kecerdasan intelektual terhadap hasil belajar bahasa Indonesia baku menggunakan bantuan SPSS 24.0. Dari tabel di atas, diperoleh nilai $\mathrm{Sig}=0,000<0,05$, maka $\mathrm{H}_{0}$ ditolak dan $\mathrm{H}_{1}$ diterima, maka terdapat pengaruh yang signifikan kecerdasan intelektual terhadap hasil belajar bahasa Indonesia baku. Hal ini juga diperjelas oleh hasil a $F_{\text {hitung }}=23,602$ dan $F_{\text {tabel }}=4,41$. Ini memiliki makna bahwa kecerdasan intelektual siswa memiliki pengaruh terhadap hasil belajar bahasa Indonesia baku.

\section{Pengujian hipotesis 3}

Hipotesis ini diuji dengan melihat koefisien signifikan. Jika nilai sig $>0,05$; maka Ho diterima dan $\mathrm{H}_{1}$ ditolak. Sebaliknya jika nilai sig < 0,05 ; maka $\mathrm{H}_{1}$ diterma dan Ho ditolak. Terdapat pengaruh interaksi model pembelajaran dan kecerdasan intelektual terhadap hasil belajar bahasa Indonesia baku (A dan B). Untuk pengujian hipotesis pengaruh interaksi model pembelajaran (NHT dan konvensional) dan kecerdasan intelektual (tinggi dan rendah), terhadap hasil belajar bahasa Indonesia baku menggunakan bantuan SPSS 24.0. Dari perhitungan di atas diperoleh nilai Sig $=0,617$ $>0,05$. Maka $H_{0}$ diterima. Ini memiliki arti bahwa tidak terdapat interaksi model pembelajaran dan kecerdasan intelektual terhadap hasil belajar bahasa Indonesia baku sementara $F_{\text {hitung }}=0,254<\mathrm{F}_{\text {tabel }}=4,41$. Ini berarti memperjelas pembuktian bahwa tidak terdapat pengaruh interaksi sehingga tidak diperlukan uji lanjut.

\section{Pembahasan}

Hasil penelitian menunjukkan bahwa terdapat perbedaan hasil belajar bahasa Indonesia baku siswa dalam pelajaran bahasa Indonesia bila ditinjau dari model pembelajaran yang dipergunakan seperti model pembelajaran NHT dan model pembelajaran konvensional serta tingkatan kecerdasan intelektual tinggi dan rendah.

Terdapat Pengaruh model pembelajaran terhadap hasil belajar bahasa Indonesia baku siswa. Hasil penelitian pada tabel, menunjukkan bahwa model pembelajaran sig= $0,01<0,05$, maka dapat di artikan bahwa terdapat pengaruh yang signifikan model pembelajaran terhadap hasil belajar bahasa Indonesia baku. Sehingga dapat disimpulkan terdapat perbedaan pengaruh yang signifikan penggunaan model pembelajaran NHT dan model pembelajaran konvensional terhadap hasil belajar bahasa Indonesia baku. Rata-rata hasil belajar bahasa Indonesia baku yang belajar dengan model pembelajaran NHT lebih baik daripada yang belajar dengan menggunakan model pembelajaran konvensional. Hal ini terbukti dari analisis deskriptif, diperoleh hasil belajar bahasa indonesia baku siswa yang belajar dengan model pembelajaran NHT yaitu nilai terendah 71 nilai tertinggi 98 nilai rata-rata sebesar 82,45 dan simpangan baku sebesar 8,445. Sedangkan pada kelompok siswa yang belajar dengan menggunakan model pembelajaran konvensional diperoleh hasil belajar bahasa Indonesia baku nilai terendah 67 , nilai tertinggi 84 , nilai rata-rata 74,35 dan simpangan baku 8,869 .

Berdasarkan data tersebut, telah teruji bahwa hasil belajar bahasa Indonesia baku siswa yang belajar dengan model pembelajaran NHT lebih tinggi secara signifikan daripada yang belajar dengan model pembelajaran konvensional. Data hasil penelitian ini bisa menjadi bahan bagi seorang pendidik untuk lebih meningkatkan penguasaan tentang model-model pembelajaran dan memilih model pelajaran yang tepat dengan keadaan siswa dan dapat memotivasi keaktifan siswa dalam proses pembelajaran sehingga hasil belajar bahasa Indonesia yang peroleh siswa pada khususnya dan semua mata pelajaran hasilnya memuaskan. 
Terdapat pengaruh kecerdasan intelektual terhadap hasil belajar bahasa Indonesia baku siswa. Hasil penelitian pada tabel, menunjukkan bahwa pada kecerdasan intelektual diperoleh sig $=0,000<0,005$, berarti terdapat pengaruh yang signifikan kecerdasan intelektual terhadap hasil belajar bahasa Indonesia baku siswa. Berdasarkan data descriptive statistics, terlihat bahwa hasil belajar bahasa Indonesia baku siswa dari kelompok yang kecerdasan intelektual tinggi nilai rata-ratanya 83,70 dan dari kelompok siswa yang mempunyai kecerdasan intelektuan rendah nilai rata-ratanya 73,10 , yang berarti ada perbedaan yang signifikan hasil belajar bahasa Indonesia baku pada kelompok siswa yang mempunyai kecerdasan intelektual tinggi dan kelompok siswa yang mempunyai kecedasan intelektual rendah.

Bagi seorang pendidik, sangat penting menguasai kemampuan dalam memetakan kecerdasan intektual peserta didiknya dengan cara bekerja sama dengan guru psikologi atau bimbingan konseling yang kompeten dalam pengukuran kecerdasan intelektual peserta didiknya. Guru diharapkan dapat memperoleh data tentang kecerdasan intelektual siswa-siswanya dan mengelompokkan siswa-siswanya sebagai dasar dalam menentukan model pembelajaran di kelas, sehingga dapat mencapai hasil belajar yang memuaskan semua pihak.

Tidak terdapat pengaruh interaksi model pembelajaran dan kecerdasan intelektual terhadap hasil belajar bahasa Indonesia baku siswa. Hasil penelitian pada tabel, menunjukan bahwa Interaksi model pembelajaran dan kecerdasan intelektual sig=0,617 $>0,05$, ini berarti tidak terdapat pengaruh interaksi model pembelajaran dan kecerdasan intelektual terhadap hasil belajar bahasa Indonesia sehingga tidak diperlukan uji lanjut.

\section{SIMPULAN}

Berdasarkan hasil dan pembahasan, dapat disimpulkan sebagai berikut:

1. Terdapat pengaruh yang signifikan model pembelajaran terhadap hasil belajar bahasa Indonesia baku siswa. Hal ini terbukti dengan hasil model pembelajaran pada tabel uji interaksi diperoleh sig $=0,001$; sig $<0,05$, maka tolak $\mathrm{H}_{0}$ dan terima $\mathrm{H}_{1}$. Hal ini juga diperjelas dengan hasil $\mathrm{F}_{\text {hitung }}=13,782>\mathrm{F}_{\text {tabel }}=4,41$.

2. Terdapat pengaruh yang signifikan kecerdasan intelektual hasil belajar bahasa Indonesia baku siswa. Hal ini terbukti dengan hasil model pembelajaran pada tabel uji interaksi diperoleh sig $=0,001$; sig $<0,05$, maka tolak $\mathrm{H}_{0}$ dan terima $\mathrm{H}_{1}$. Hal ini juga diperjelas dengan $\mathrm{F}_{\text {hitung }}(\mathrm{Ak})>\mathrm{F}_{\text {tabel }}(\mathrm{Ak}) ; 23,602>4,41$.

3. Tidak terdapat pengaruh interaksi antara model pembelajaran dan kecerdasan intelektual terhadap hasil belajar bahasa Indonesia baku siswa. Hal ini terbukti dengan hasil tabel uji interaksi diperoleh sig $=0,617$; sig > 0,05 maka terima $\mathrm{H}_{0}$ dan tolak $\mathrm{H}_{1}$ dan $F_{\text {hitung }}=0,254<\mathrm{F}_{\text {tabel }}=4,41$.

\section{DAFTAR PUSTAKA}

Acher, dkk. ( 2011). Explicit instruction effective and efficient teaching. The Gullford Press : New York.

Anderson, B. (2008). Memahamiimagined communities. Yogyakarta: Insist Press Anderson, dkk. (2001). A taxonomy for learning teaching and assesing. New York: Arifin, Z. ( 2008). Kaidah bahasa Indonesia. Jakarta: Gunung Agung Lapasau, M \& Arifin, Z. (2016). Sosiolinguistik. Tangerang: Pustaka Mandiri. 
Diskursus: Jurnal Pendidikan Bahasa Indonesia

Vol. 1, No. 1, April 2018, pp. 82-96

p-ISSN: 2615-4935

e-ISSN: 2615-4943

Lie, A. (2014). Cooperative learning, mempraktikan cooperative learning di ruangruang kelas. Jakarta: Grasindo.

Sanjaya, W. (2006). Strategi pembelajaran. Jakarta: Kencana Prenada Media Group.

Slavin, R. E. (2011). Psikologi pendidikan teori dan praktik. Jakarta: PT Indeks.

Sudjana,N. (2010). Penilaian hasil proses belajar mengajar:cetakan XV, Bandung:PT.

Ramaja Rosdakarya

Trianto.(2015). Mendesain model pembelajaran inovatif-progresif dan kontekstual: konsep, landasan, dan implementasinya pada kurikulum 2013 kurikulum tematik integratif/KTI. Jakarta: Kencana Prenada Media Group

McMillen, C, dkk. (2014)."Effects of Numbered Heads Together on the Science Quiz Performance of 9th Grade Students ", Journal of Evidence Based Practices for Schools, Vol. 15 (1). 